\title{
KAJIAN PEMASARAN RELASIONAL BAYAM JEPANG (HORENSO) ORGANIK DI INAGREEN FARM, DILEMA ANTARA HARAPAN DAN KENYATAAN
}

\author{
STUDY OF RELATIONAL MARKETING ON ORGANIC JAPAN SPINACH \\ (HORENSO) IN INAGREEN FARM, DILEMMA BETWEEN HOPES AND REALITY
}

\author{
Elly Rasmikayati ${ }^{1}$, Endah Djuwendah ${ }^{1}$, Bobby Rachmat Saefudin*2, Nur Syamsiyah ${ }^{1}$, \\ Amallia Ridhatillah ${ }^{1}$
}

${ }^{1}$ Fakultas Pertanian, Universitas Padjadjaran, Jl. Ry Bandung-Sumedang KM.21 Jatinangor, 45363

${ }^{2}$ Fakultas Pertanian, Ma'soem University, Jl. Raya Cipacing No. 22 Jatinangor, 45363

*E-mail: bobbyrachmat@masoemuniversity.ac.id

(Diterima 12-01-2020; Disetujui 20-01-2020)

\begin{abstract}
ABSTRAK
Tingginya trend permintaan konsumen sayuran organik telah memicu meningkatnya permintaan dari ritel modern terhadap produk horenso organik di InaGreen Farm yang berperan sebagai pemasok horenso organik bagi ritel modern. Akan tetapi, tingginya permintaan tersebut tidak terpenuhi secara optimal dikarenakan adanya berbagai kendala. Tujuan makalah ini adalah: 1) untuk mengetahui pelaksanaan pemasaran yang dilakukan InaGreen Farm dengan mitra dan ritel modern, dan; 2) mengetahui kendala yang dihadapi agar dapat memberikan rekomendasi kepada InaGreen Farm dalam pelaksanaan pemasaran produk horenso organik dengan mitra dan ritel modern. Desain penelitian yang digunakan adalah kualitatif dengan metode deskriptif. Informan yang terlibat dalam penelitian ini dipilih dengan menggunakan teknik purposive sampling. Hasil penelitian menunjukkan bahwa: 1) pelaksanaan pemasaran antara InaGreen Farm dengan pihak mitra dan ritel modern tidak sepenuhnya berjalan dengan baik dikarenakan masih terdapat hal-hal seperti adanya perilaku oportunistik atau pelanggaran perjanjian yang dilakukan InaGreen Farm dalam pemasaran relasional yang terjalin, dengan tidak memenuhi permintaan dari pihak ritel modern secara optimal; serta 2) kendala yang dihadapi InaGreen Farm dalam menjalin pemasaran relasional dengan pihak mitra dan ritel modern adalah rendahnya produksi horenso organik di InaGreen Farm dikarenakan kurang luasnya lahan produksi yang dimiliki, tidak adanya perjanjian atau kesepakatan tertulis dengan pihak mitra dalam menjalankan hubungan kerjasama.
\end{abstract}

Kata kunci: pemasaran relasional, horenso, bayam jepang, sayuran organik, dilema, kendala, harapan dan kenyataan

\section{ABSTRACT}

The high demand trend of organic vegetable consumers has triggered an increase in demand from modern retail for organic horenso products at InaGreen Farm, which acts as a supplier of organic horenso for modern retail. However, the high demand was not optimally fulfilled due to various obstacles. The purpose of this paper is: 1) to find out the marketing implementation of InaGreen Farm with modern retail partners and partners, and;2) know the obstacles faced in order to be able to provide recommendations to InaGreen Farm in the implementation of marketing of organic horenso products with partners and modern retailers. The research design used is qualitative descriptive method. The informants involved in this study were selected using purposive sampling technique. The results showed that: 1) marketing implementation between InaGreen Farm and partners and modern retailers did not run well because there were still things like opportunistic behavior or breach of agreement committed by InaGreen Farm in relational marketing that was intertwined, by not meeting the demand optimally from modern retailers; and 2) the obstacle faced by InaGreen Farm in establishing relational marketing with partners and modern retailers is the low 
Kajian Pemasaran Relasional Bayam Jepang (Horenso) Organik, Dilema Antara Harapan Dan Kenyataan

Elly Rasmikayati, Endah Djuwendah, Bobby Rachmat Saefudin, Nur Syamsiyah, Amallia Ridhatillah

organic horenso production at InaGreen Farm due to the lack of production area owned, there is no written agreement or agreement with partners in running a cooperative relationship.

Keywords: relational marketing, horenso, japanese spinach, organic vegetables, dilemmas, constraints, hopes and reality

\section{PENDAHULUAN}

InaGreen Farm adalah salah satu perusahaan yang memilih untuk bergerak dalam bisnis komoditas sayuran organik yang berperan sebagai pemasok sayuran organik bagi ritel modern. InaGreen Farm telah menjalankan bisnis sayuran organik sejak tahun 2008. Sebagai perusahaan yang masih berkembang, InaGreen Farm telah menunjukkan potensi yang cukup besar dikarenakan telah berhasil menarik minat banyak ritel modern untuk menyalurkan produk sayuran organik yang dihasilkan. Hal ini dibuktikan dengan tingginya permintaan produk sayuran organik dari pihak ritel modern. Permintaan konsumen ini sejatinya merupakan peluang yang dapat dimaksimalkan oleh pihak petani, supplier dan pihak ritel modern (Rasmikayati, 2018). Akan tetapi, tingginya permintaan tersebut belum terpenuhi seluruhnya. Produksi sayuran organik yang cenderung fluktuatif karena sangat bergantung dengan kondisi alam menjadi penyebab utama yang menghambat pihak perusahaan untuk memenuhi seluruh permintaan tersebut secara optimal
(Forum Penelitian Agro Ekonomi, 2012).

Salah satu komoditas sayuran organik hasil produksi InaGreen Farm yang prospektif tetapi masih rendah jumlah produksinya adalah Horenso (bayam jepang).

Horenso adalah komoditas yang beberapa tahun terakhir ini mulai diminati oleh pebisnis di subsektor hortikultura. Jenis sayuran ini dinilai sangat prospektif karena harganya yang tinggi bahkan berkali-kali lipat dari sayuran lokal. Usia panen horenso juga singkat dan teknik budidayanya relatif mudah. Horenso diminati oleh konsumen di Indonesia karena rasanya yang enak, lunak dan dapat melancarkan pencernaan. Selain itu, bayam asal negeri sakura ini sangat kaya mineral dan memiliki kandungan vitamin yang sangat lengkap (Adhi, 2014). Tingginya permintaan dan rendahnya produksi horenso di InaGreen Farm dapat dilihat pada Gambar 1. 


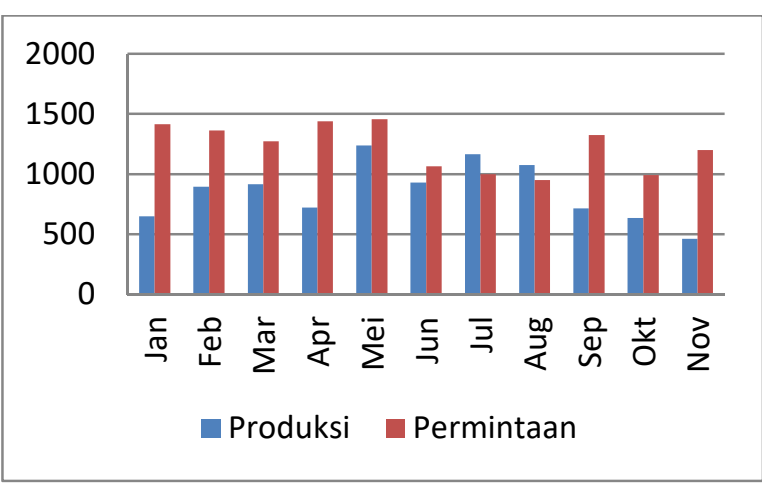

Gambar 1. Grafik Perbandingan Jumlah Permintaan dengan Jumlah Produksi Horenso InaGreen Farm Januari-November 2015

Sumber: Data InaGreen Farm, diolah

Gambar 1 menunjukkan adanya perbedaan yang cukup signifikan antara jumlah permintaan dari ritel modern dan jumlah produksi horenso di perusahaan. Permintaan tertinggi terjadi pada bulan Mei 2015 dengan total permintaan sebesar 1.458 pak produk horenso, sedangkan total produksi horenso yang dihasilkan InaGreen Farm pada bulan Mei hanya 1.239 pack, yang artinya terdapat selisih sebesar 219 pack. Angka ini bukanlah jumlah selisih yang sedikit dan tentunya akan sangat berpengaruh dan berisiko bagi keberlanjutan bisnis perusahaan sebagai pemasok produk horenso organik. Merujuk pada Rasmikayati dkk. (2017) risiko pemasaran berpengaruh signifikan menurunkan tingkat pendapatan. Risiko yang mungkin dapat terjadi pada perusahaan jika tidak dapat memenuhi permintaan ritel modern akan produk horenso organik secara optimal adalah berpindahnya pihak ritel modern ke pemasok lain. Kondisi inilah yang dihindari oleh InaGreen Farm.

Dalam pemenuhan pasokan produk horenso organik, InaGreen Farm hanya memiliki 1 mitra yang membantu menyediakan pasokan produk. Mitra ini adalah Buana Tani, yang membantu menyediakan kekurangan pasokan produk horenso organik untuk InaGreen Farm.

Adanya peningkatan pendapatan dan timbulnya kesadaran akan pentingnya kesehatan telah membuat masyarakat mengubah gaya hidupnya menuju gaya hidup sehat. Hal ini menjadi salah satu penyebab yang memicu munculnya tren sayuran organik di kalangan masyarakat. Bahkan bukan hanya kalangan dewasa saja, saat ini minat para remaja pun untuk mengkonsumsi sayuran organik sudah meningkat (Pardian, 2017). Salah satu komoditas sayuran organik yang tengah digemari adalah horenso (bayam jepang).

Tingginya permintaan akan horenso organik dari masyarakat di ritel modern, tentu menjadi peluang besar yang dapat dimanfaatkan oleh para pebisnis sayuran organik, salah satunya pemasok horenso organik seperti InaGreen Farm untuk memenuhi permintaan tersebut.

Akan tetapi, produksi horenso organik yang cenderung tidak stabil dan 
sangat fluktuatif karena bergantung dengan kondisi alam membuat InaGreen Farm tidak dapat memenuhi permintaan tersebut secara optimal, sehingga tujuan yang ingin dicapai dalam penelitian ini adalah sebagai berikut: 1) Mengetahui pelaksanaan pemasaran horenso organik yang dilakukan InaGreen Farm dengan mitra dan ritel modern; dan 2) Mengetahui kendala yang dihadapi InaGreen Farm dalam pelaksanaan pemasaran produk horenso organik dengan mitra dan ritel modern.

\section{METODE PENELITIAN}

Objek dalam penelitian ini adalah pemasaran relasional atau relationship marketing antara InaGreen Farm dengan mitra dan ritel modern. Penelitian akan dilaksanakan di InaGreen Farm, yang lokasi kebun dan kantor perusahaannya berada di Desa Cikahuripan, Kecamatan Lembang, Kabupaten Bandung Barat.

Penelitian ini dilakukan dengan desain penelitian kualitatif dengan metode deskriptif yang bertujuan menggambarkan pola hubungan yang bersifat interaktif dan menggambarkan realitas yang kompleks. Penelitian kualitatif memberikan penggambaran secara mendalam mengenai situasi atau proses yang diteliti (Sugiyono, 2014). Teknik penelitian berupa studi kasus dengan menjelaskan dan memahami objek yang diteliti. Metode yang dilaksanakan melalui observasi secara mendalam dan wawancara kepada pakar atau ahli sebagai key informant yang berkompeten di bidangnya.

Variabel penelitian terbagi dalam 2 dimensi yaitu dimensi Pelaksanaan Pemasaran Relasional dan dimensi Kendala dalam Pelaksanaan Pemasaran Relasional. Variabel Pelaksanaan pemasaran relasional dimulai dengan kegiatan jual beli antara kedua belah pihak dan memiliki dua dimensi yang dijelaskan sebagai berikut:

1. Kegiatan Jual Beli Produk Horenso Organik

2. Dimensi kepercayaan (trust) yang terjalin antara InaGreen Farm mitra dengan ritel modern (Alrubaiee, 2010).

3. Dimensi komitmen (commitment) yang terjalin antara InaGreen Farm dengan mitra dan ritel modern. (Erfansyah, 2014 dan Purwono, 2010).

Sementara itu, variabel Kendala dalam Pelaksanaan Pemasaran Relasional merupakan beberapa kendala yang dihadapi perusahaan dalam pelaksanaan pemasaran relasional dengan mitra dan pelanggan, diantaranya: 
1. Usahatani Horenso Organik

2. Harga Produk

3. Hubungan Kerjasama

4. Kompetitor

Kemudian, teknik analisi data yang digunakan pada penelitian ini yaitu rancangan analisis deskriptif untuk dapat mengetahui pelaksanaan pemasaran relasional antara InaGreen Farm dengan mitra dan ritel modern serta kendala yang dihadapi di dalamnya. Teknik analisis deskriptif yang digunakan adalah teknik analisis yang dikemukakan oleh Miles dan Huberman dalam Sugiyono (2014) yang meliputi : 1) Reduksi Data; 2) Penyajian Data; dan 3) Penarikan kesimpulan/ verifikasi.

Menurut Miles dan Huberman dalam Sugiyono (2014), reduksi data adalah proses merangkum, menggolongkan, mengarahkan, membuang yang tidak perlu dan menggolongkan data sedemikian rupa sehingga dapat ditarik kesimpulankesimpulan di dalamnya. Dengan demikian, data yang telah direduksi akan menjadi sebuah gambaran yang memudahkan peneliti dalam pengumpulan data. Dalam penelitian ini, reduksi data difokuskan pada data yang mendeskripsikan pelaksanaan pemasaran relasional melalui dimensi kepercayaan dan komitmen antara InaGreen Farm dengan pihak mitra dan ritel modern serta kendala yang dihadapi dalam pelaksanaannya. Selanjutnya, data yang diperoleh diolah dan dianalisis menggunakan analisis deskriptif, yaitu analisis dengan mendeskripsikan data yang terkumpul sebagaimana adanya tanpa membuat kesimpulan yang berlaku umum atau generalisasi.

Setelah data direduksi, langkah selanjutnya adalah penyajian data. Dalam penelitian ini, penyajian data menggunakan teks yang bersifat naratif karena menurut Miles dan Huberman dalam Sugiyono (2014) penyajian data yang paling sering digunakan dalam penelitian kualitatif adalah teks yang bersifat naratif. Namun, penyajian data dapat juga menggunakan gambar, tabel, matriks, grafik, jaringan, dan bagan yang dapat memberikan gambaran yang jelas mengenai bagaimana pelaksanaan pemasaran relasional antara InaGreen Farm dengan mitra dan ritel modern serta mengetahui kendala apa saja yang dihadapi selama proses pelaksanaan pemasaran.

Langkah ketiga dalam analisis data kualitatif menurut Miles dan Huberman dalam Sugiyono (2014) adalah penarikan kesimpulan dan verifikasi. Kesimpulan 
awal yang dikemukakan masih bersifat sementara, dan akan berubah bila tidak ditemukan bukti-bukti yang kuat yang mendukung pada tahap pengumpulan data berikutnya. Kesimpulan dalam penelitian kualitatif merupakan temuan baru yang sebelumnya belum pernah ada. Temuan dapat berupa deskripsi atau gambaran suatu obyek yang sebelumnya masih belum jelas, sehingga setelah diteliti menjadi jelas, dapat berupa hubungan kausal atau interaktif dan hipotesis atau teori.

Setelah proses penyajian data, kesimpulan yang akan dihasilkan dalam penelitian ini nantinya akan menjawab seluruh pertanyaan penelitian mengenai pelaksanaan pemasaran relasional antara InaGreen Farm dengan mitra dan ritel modern serta mengetahui kendala yang dihadapi dalam pelaksanaannya, sehingga peneliti dapat memberikan rekomendasi, sesuai dengan hasil yang telah diteliti, kepada InaGreen Farm mengenai hal-hal yang harus dilakukan agar tetap dapat menjaga dan memelihara hubungan jangka panjang dengan mitra dan ritel modern meskipun terdapat beberapa kendala dalam pelaksanaannya.

\section{HASIL DAN PEMBAHASAN \\ Pelaksanaan Pemasaran Horenso Organik}

Jumlah permintaan horenso organik yang tertera pada tabel $1 \mathrm{di}$ atas bersifat kondisional mengikuti banyaknya permintaan dari para konsumen di masing-masing ritel modern. Salah satu contohnya di ritel modern Toserba A. Pihak manajemen Toserba A melakukan strategi pemasaran dalam penjualan produk sayuran organik dengan memberikan harga promo/diskon untuk setiap pembelian produk sayuran organik pada hari senin, kamis, sabtu, dan minggu.

Pada hari-hari tersebut, permintaan konsumen akan meningkat sehingga jumlah permintaan terhadap produk horenso organik di InaGreen Farm pun akan bertambah menjadi 20-30 pak/hari.

Tabel 1. Jumlah Permintaan dari Ritel Modern

\begin{tabular}{lc}
\hline \multicolumn{1}{c}{ Ritel Modern } & $\begin{array}{c}\text { Jumlah Permintaan } \\
\text { (pak/hari) }\end{array}$ \\
\hline Toserba A & 10 \\
Toserba B & 15 \\
Toserba C & $15-20$ \\
Transmart Carrefour & 4 \\
Cipadung & \\
Sumber: InaGreen & \\
\multicolumn{1}{c}{ Jumlah produk } & yang diminta
\end{tabular}

InaGreen Farm untuk menambah pasokan produk horenso organik di perusahaan kepada mitranya, Buana Tani, adalah sebanyak $15 \mathrm{pak} / \mathrm{hari}$ atau sekitar $4 \mathrm{~kg}$ dalam satu kali pemesanan. Jumlah ini 
dapat berubah-ubah, disesuaikan dengan jumlah kekurangan produk horenso organik di perusahaan untuk memenuhi permintaan ritel modern. Harga yang ditawarkan Buana Tani sebagai pihak mitra untuk membantu menambah pasokan produk horenso organik yang dibutuhkan InaGreen Farm adalah Rp 18.000/kg. Harga tersebut adalah harga maksimal. Jika harga yang ditawarkan Buana Tani di atas harga tersebut, maka InaGreen Farm akan menolak harga tersebut.

Di sisi lain, harga yang ditawarkan InaGreen Farm untuk setiap produk horenso organik yang dipesan oleh ritel modern berbeda-beda. Untuk ritel modern Toserba A, Toserba B, dan Toserba C harga yang ditawarkan InaGreen Farm adalah Rp 8.000/pak. Sedangkan, untuk ritel modern Transmart Carrefour, harga yang ditawarkan InaGreen Farm adalah Rp 8.500/pak.

InaGreen Farm melakukan pemesanan horenso organik kepada pihak mitra secara tidak langsung, yaitu dengan memesan via telepon. Terkadang, pihak InaGreen Farm juga melakukan pemesanan secara langsung dengan datang ke kebun Buana Tani. Pemesanan dilakukan setelah mengetahui bahwa jumlah panen produk horenso organik di hari itu ternyata tidak sesuai dengan jumlah permintaan pelanggan. Untuk produk horenso yang dipesan oleh ritel modern, InaGreen Farm akan mendistribusikan produk tersebut pada keesokan harinya ke seluruh ritel modern. Produk horenso didistribusikan menggunakan sepeda motor dengan cara diletakkan dalam sebuah kontainer besar. Persiapan pengiriman produk dilakukan sejak pukul 06.00 dan akan sampai di setiap ritel modern sekitar pukul 07.30 08.30 .

\section{Analisis Kepercayaan antara InaGreen} Farm dengan Mitra dan Ritel Modern

Selain dengan pihak mitra, wawancara juga dilakukan dengan setiap supervisor fresh atau buyer fresh dari masing-masing ritel modern, yaitu Toserba A, Toserba B, Toserba C, dan Transmart Carrefour Cipadung. Dalam wawancara yang dilakukan dengan Pak Sugih selaku Supervisor Fresh di Toserba A, Ia mengatakan bahwa pihak InaGreen Farm tidak pernah bersikap oportunis atau melanggar perjanjian dalam melakukan kerjasama. Sejauh ini, pihak InaGreen Farm selalu berusaha untuk memenuhi setiap permintaan dari Toserba A. Jika InaGreen Farm tidak dapat memenuhi permintaan sesuai dengan jumlah yang 
diminta, InaGreen Farm selalu langsung memberikan konfirmasi via telepon setelah menerima venditor yang berisi daftar pesanan dari pihak Toserba A. Rendahnya perilaku oportunis yang dilakukan InaGreen Farm membuat pihak Toserba A memiliki kepercayaan untuk tetap mempertahankan pemasaran relasional yang telah terjalin.

Di ritel modern lain, yaitu Toserba B, Pak Iwan selaku Supervisor mengatakan bahwa InaGreen Farm tidak pernah berperilaku oportunis karena InaGreen Farm selalu menepati janjinya untuk memenuhi permintaan dari Toserba B. Di saat kompetitor atau pemasok lain di Toserba B hanya memenuhi 70\% permintaan, InaGreen Farm dapat memenuhi $95 \%$ dari total keseluruhan permintaan dari Toserba B. Tidak adanya perilaku oportunis yang dilakukan InaGreen Farm membuat Toserba B memiliki kepercayaan yang tinggi terhadap InaGreen Farm sehingga pemasaran relasional yang terjalin dapat tetap berjalan dengan baik.

Di sisi lain, Ibu Aprilistanti selaku Buyer Fresh di Toserba C memiliki pendapat yang berbeda dengan pihak Toserba A dan Toserba B. Beliau berpendapat bahwa InaGreen Farm memiliki perilaku oportunis yang tinggi.
Permintaan konsumen terhadap produk horenso organik di Toserba $\mathrm{C}$ sangat tinggi. Akan tetapi, InaGreen Farm tidak memanfaatkan peluang ini dan sangat jarang memenuhi permintaan pihak Toserba $\mathrm{C}$ secara optimal. Jika tidak dapat memenuhi permintaan, InaGreen Farm tidak pernah langsung memberikan konfirmasi kepada pihak Toserba C. Terakhir kalinya InaGreen Farm memenuhi permintaan dari pihak Toserba C sudah terjadi sangat lama yaitu pada bulan November 2015. Timbulnya kekecewaan akibat perilaku oportunis yang dilakukan InaGreen Farm, membuat pemasaran relasional yang terjalin dengan Toserba $\mathrm{C}$ tidak berjalan dengan baik hingga akhirnya saat ini pihak Toserba $\mathrm{C}$ tidak pernah melakukan pemesanan kembali terhadap produk InaGreen Farm. Hal ini sejalan dengan pernyataan Natawidjaja dkk. (2017) bahwa pelanggan akan berpindah ke tempat lain jika terjadi ketidakpuasan atau barang yang dimita tidak tersedia.

\section{Analisis Komitmen antara InaGreen} Farm dengan Mitra dan Ritel Modern

Berdasarkan hasil wawancara dengan pihak mitra, ditunjukkan dalam tabel 2 di atas bahwa Buana Tani tidak memiliki komitmen terhadap InaGreen 
Farm. Pihak mitra merasa tidak memiliki keterikatan dengan pihak InaGreen Farm. Hal ini dikarenakan pihak mitra selalu berusaha melakukan kegiatan produksi yang mandiri secara optimal sehingga tidak perlu bergantung kepada pihak InaGreen Farm atau pihak manapun. Selain itu, hubungan kerjasama dengan pihak mitra pun tidak dibangun di atas perjanjian tertulis, sehingga pihak mitra merasa tidak memiliki keharusan untuk membantu InaGreen Farm dalam menambah kekurangan pasokan dan membuat InaGreen Farm tidak dapat bergantung dengan pihak mitra. Oleh karena itu, tidak adanya komitmen dari pihak mitra terhadap InaGreen Farm membuat pemasaran relasional yang terjalin di antara keduanya menjadi sulit untuk dipertahankan.

Di pihak ritel modern, Toserba A dan Toserba B memiliki bentuk komitmen afektif dikarenakan kedua ritel modern tersebut berpendapat bahwa pemasaran relasional yang terjalin dengan InaGreen Farm saling menguntungkan satu sama lain. Adanya pemberian kualitas pelayanan yang baik dan pemenuhan permintaan secara optimal yang dilakukan InaGreen Farm terhadap Toserba A dan Toserba B membuat keduanya memiliki komitmen untuk dapat mempertahankan pemasaran relasional dalam jangka panjang dengan InaGreen Farm.

\section{Kendala Dalam Pelaksanaan Pemasaran Horenso Organik}

\section{Usahatani Horenso Organik}

Rendahnya produksi horenso organik di InaGreen Farm dikarenakan kurang luasnya lahan produksi yang dimiliki, membuat permintaan dari pihak ritel modern tidak dapat dipenuhi secara optimal.

\section{Harga Produk}

Dalam penentuan harga produk horenso organik, pihak ritel modern tidak pernah melakukan perubahan harga beli produk secara sepihak. Jika pihak ritel modern sedang melakukan kegiatan promosi dengan memberikan harga yang lebih rendah pada konsumen, maka pihak ritel modern akan melakukan negosiasi terlebih dahulu dengan InaGreen Farm untuk mengetahui kesediaannya dalam mendukung kegiatan promosi tersebut melalui pemberian harga yang lebih rendah untuk jumlah produk yang lebih banyak, sehingga nantinya tidak akan ada pihak yang merasa dirugikan. Kegiatan promosi ini merupakan salah satu atribut yang paling dominan dalam menentukan keputusan konsumen untuk membeli produk (Rasmikayati dkk., 2017). 
Kajian Pemasaran Relasional Bayam Jepang (Horenso) Organik, Dilema Antara Harapan Dan Kenyataan

Elly Rasmikayati, Endah Djuwendah, Bobby Rachmat Saefudin, Nur Syamsiyah, Amallia Ridhatillah

\section{Hubungan Kerjasama}

Dalam hubungan kerjasamanya dengan pihak mitra, Buana Tani, InaGreen Farm tidak pernah melakukan pemutusan hubungan kerjasama secara sepihak.

\section{Kompetitor}

Terdapat dua jenis kompetitor yang dimaksud dalam penelitian ini, yaitu perusahaan sejenis yang menjadi pesaing/kompetitor karena bekerjasama juga dengan Buana Tani, satu-satunya mitra InaGreen Farm, dan perusahaan yang menjadi pesaing di ritel modern karena menjual produk sejenis yaitu horenso organik. Adanya kompetitor dalam kegiatan pemasaran tentu menjadi kendala utama bagi suatu perusahaan untuk tetap dapat bertahan dalam persaingan yang ketat di dunia bisnis (Sari dkk., 2019), dalam hal ini dunia bisnis sayuran organik.

\section{KESIMPULAN DAN SARAN}

Berdasarkan hasil pembahasan dari penelitian yang dilakukan, dapat disimpulkan bahwa pelaksanaan pemasaran horenso organik antara InaGreen Farm dengan pihak mitra dan ritel modern adalah sebagai berikut:

a. Kegiatan jual beli horenso organik sudah berjalan dengan baik. Jika InaGreen Farm mengalami kekurangan pasokan horenso, maka akan langsung membeli tambahan produk horenso kepada pihak mitra sebanyak 15 pak atau sekitar $4 \mathrm{~kg}$ horenso dalam satu kali pemesanan dengan harga Rp 18.000/kg.

b. Pada dimensi kepercayaan dalam pemasaran relasional yang terjalin tidak sepenuhnya berjalan dengan baik dikarenakan masih terdapat perilaku oportunistik dengan adanya pelanggaran perjanjian yang dilakukan InaGreen Farm untuk memenuhi permintaan dari pihak ritel modern secara optimal karena ketidaksesuaian jumlah produk yang diberikan dengan jumlah produk yang diminta.

c. Pada dimensi komitmen dalam pemasaran relasional yang terjalin dengan pihak ritel modern sudah berjalan dengan baik. Akan tetapi, dengan pihak mitra tidak sepenuhnya berjalan dengan baik. Pihak mitra berusaha melakukan produksi yang mandiri dan tidak bergantung dengan pihak InaGreen Farm.

Kendala yang dihadapi InaGreen Fam dalam pelaksanaan pemasaran horenso organik dengan pihak mitra dan ritel modern adalah sebagai berikut:

a. Rendahnya produksi horenso organik di InaGreen Farm dikarenakan kurang 
luasnya lahan produksi yang dimiliki, membuat permintaan dari pihak ritel modern tidak dapat dipenuhi secara optimal.

b. Tidak adanya perjanjian atau kesepakatan tertulis dengan pihak mitra, Buana Tani, dalam menjalankan hubungan kerjasama, membuat pihak mitra tidak merasa terikat dan berkewajiban untuk selalu membantu menambah kekurangan produk horenso organik InaGreen Farm demi memenuhi permintaan pelanggan (ritel modern)..

\section{DAFTAR PUSTAKA}

Adhi, Nowo. 2014. Bayam Jepang Horenso Sayuran Organik Anti Penuaan. Jakarta

Alrubaiee, Laith. 2010. Investigate The Impact of Relationship Marketing Orientation On Customer Loyalty: The Customer's Perspective. Middle East University.

Erfansyah, Tengku. 2014. Analisis Faktor-Faktor yang Mempengaruhi Loyalitas Konsumen Telkomsel di Bandar Lampung. Tesis Magister Manajemen Program Pascasarjana Universitas Lampung.

Forum Penelitian Agro Ekonomi. 2012. Pengembangan Pertanian Organik di Indonesia. Bogor: Pusat Sosial Ekonomi dan Kebijakan Pertanian.

Natawidjaja, R. S., Sulistiowaty, L., Kusno, K., Aryani, D., \& Rachmat,
B. (2017). Analisis Preferensi, Kepuasan, dan Kesediaan Konsumen Membayar Beras Di Kota Bandung. Diakses melalui: http://repository.unsri.ac.id/10520/

Pardian, P. (2017). Persepsi Dan Minat Petani Muda Dalam Budidaya Sayuran Swiss Chard Organik. Dharmakarya, 6(3). Diakses melalui:

http://journal.unpad.ac.id/dharmaka rya/article/view/14817.

Rasmikayati, E. (2018). Kajian Potensi dan Kendala dalam Proses Usahatani dan Pemasaran Mangga Di Kabupaten Indramayu. Sosiohumaniora, 20(3), 215-221. DOI:

https://doi.org/10.24198/sosiohuma niora.v20i3.15859.

Rasmikayati, E., Pardian, P., Hapsari, H., Ikhsan, R. M., \& Saefudin, B. R. (2017). Kajian Sikap dan Perilaku Konsumen dalam Pembelian Kopi Serta Pendapatnya Terhadap Varian Produk Dan Potensi Kedainya. Mimbar Agribisnis: Jurnal Pemikiran Masyarakat Ilmiah Berwawasan Agribisnis, 3(2), 117133.

DOI:

http://dx.doi.org/10.25157/ma.v3i2. 563.

Rasmikayati, E., Sulistyowati, L., \& Saefudin, B. R. (2017). Risiko Produksi Dan Pemasaran Terhadap Pendapatan Petani Mangga: Kelompok Mana Yang Paling Berisiko. Mimbar Agribisnis: Jurnal Pemikiran Masyarakat Ilmiah Berwawasan Agribisnis, 3(2), 105-116. DOI: http://dx.doi.org/10.25157/ma.v3i2. 564. 
Sari, A. F., Rasmikayati, E., \& Saefudin, B. R. (2019). Behavioral Dynamics of Farmers and First Buyer in Marketing Mangoes in Sedong District, Cirebon Regency, West Java. Agrifor, 18(1), 63-72. Diakses melalui: $\quad$ http://ejurnal.untagsmd.ac.id/index.php/AG/article/vie $\mathrm{w} / 4072$.
Sugiyono. (2014). Metode Penelitian Pendidikan Pendekatan Kuantitatif,. Kualitatif, dan $R \& D$. Bandung: Alfabeta. 